\title{
Leaders Role on the Effectiveness of Private Pre-schools in Sodo City Administration, Wolaita Zone, Ethiopia
}

\author{
Admasu Ayele, Ashebir Bezabih \\ Department of Educational Planning and Management, Wolaita Sodo University, Wolaita Sodo, Ethiopia \\ Email address: \\ ashbeze@yahoo.com (A. Bezabih), ashebirbezabih@gmail.com (A. Bezabih)

\section{To cite this article:} \\ Admasu Ayele, Ashebir Bezabih. Leaders Role on the Effectiveness of Private Pre-schools in Sodo City Administration, Wolaita Zone, \\ Ethiopia. International Journal of Elementary Education. Vol. 8, No. 3, 2019, pp. 74-79. doi: 10.11648/j.ijeedu.20190803.14
}

Received: June 2, 2019; Accepted: August 9, 2019; Published: October 28, 2019

\begin{abstract}
The general objective of this study was to investigate leaders role on effectiveness of private preschool education in Sodo City Administration of Wolaita Zone. To achieve this objective a concurrent triangulation research design of mixed research method was employed. Data were gathered from 20 private preschools. 120 preschool teachers and 20 principals were selected by using availability sampling technique. The qualitative data were gathered from 6 supervisors, 2 City administration experts of 6 PTSA chairman. The major findings of the study indicated that, problems encountered by preschool leaders include: the absence of guidelines, shortage of resource, high turnover of teachers, lack of incentive, low salary, the absence of on-job trainings, irregularity and non-uniformity of curricula, lack of qualified teachers in the area, lack of qualified principals, and lack of safe and conducive teaching learning environment. Thus, continuous in-service trainings should be provided in the area of childhood development and leadership for preschool leaders, close and proper monitoring and support should be given to private preschools by city administration education office. Besides, preschool owners should avail essential resources, and private pre- schools should work in collaboration with parents.
\end{abstract}

Keywords: Private Pre-school, Effective Leadership, Leaders Role

\section{Introduction}

High-quality Early Childhood Care and Education (ECCE) are now recognized as a core strategy for poverty reduction. There is evidence of high returns from ECCE investments, which can contribute, to global policy priorities such as tackling child malnutrition increasing children's successful participation in school and strengthening economic development.

Besides, as noted in [7], early childhood is a critical phase for human development, and that access to high-quality ECCE can improve children's nutritional, health and education outcomes. Evidence of the long-term benefits from early intervention combines with estimates about the current loss in developmental potential, and data on the wider economic returns of early investment in children to build a persuasive case for targeted investment in quality programs.

Moreover, it is widely recognized fact that preschool education is an integral part of basic education and represents the first and essential step in achieving the goals of Education-for-All in particular and human skill formation in general [3]. The good reason is that a well-conceived quality of preschool education helps to meet the diverse needs of young children during the crucial early years of life, enhance their readiness for schooling, and have a positive and permanent influence on later schooling achievements [2]. For this reason, early education may be the single most effective intervention for helping the children, families, communities and nations break the intergenerational cycle of poverty.

Recently, ECCE has become one of the priorities for the education sector. Pre-primary education is one of the potential inputs to the overall improvement of quality of education and participating in ECCE is the right of the child. Because it is a foundation of Education for all (EFA) and the first step in meeting all the other EFA goals. This in turn contributes to the overarching Millennium Development Goal/MDG/ of reducing poverty, that also has significant contribution in economic return [10].

The main aim of pre-primary education is the all rounded development of children in order to prepare them for formal schooling. In the same way, Preschool programs aim to 
provide early developmental and educational activities to foster children's social and cognitive maturation, and to help prepare them for school. It requires high investment and trained work force [9]. In order to achieve this, the Education Sector Development Program designed four main strategies for Early Childhood Education [10].

The first strategy is to mainstream ECCE by clarifying the mandate and role of the various stakeholders and establishing a national steering committee, regional councils and Woreda technical committees. The second strategy is to enforce the monitoring and regulating the quality of ECCE delivery while the third strategy is to give direct support to quality improvement. The last strategy is to give more attention to early childcare education teacher training and development.

For implementing the above strategies, MoE develop standards for pre-primary school education since 2010 by considering educational structure, educational work guidelines and educational organization. The curriculum for pre-primary education was developed on major themes of children's developmental activities, namely proper care for appropriate development and physical strength, enabling to create reasonable relationship with others through proper use of language, using mathematical and conceptual ideas in children's day-to-day activities for studying and testing environmental interaction [10]. In the same way, the features of effective preschool education can be seen in many perspectives: to build the children's foundation stage of cognitive, physical, emotional and social development which rests on the role of competent and effective leader.

The success of any organization, be it a business, an industry or education, is highly dependent upon its leadership. The importance of leadership is well highlighted by Mulford who argues that "whatever elements of restructuring of public schooling are employed, they all have in common a strong dependence on effective school leadership for their successful implementation" [12]. Similarly, Truskie asserts that, "there is a direct link between leadership, organizational culture and performance" [17]. Silins \& Mulford also point to the important role of leadership when they propose that "leadership has been shown to influence what happens in the core business of the school: the teaching and learning" [14].

Fligsten \& Freeland extend the importance of leadership beyond the locality of the organization when they assert that the ability of organizational leaders to solve internal resource problems is a function of their abilities, knowledge and links with the outside world [5]. This external linkage highlights the importance of leadership to coordinate and to harmonize the structural-cultural dynamics which foster organizational development and learning in a way that makes a positive difference to the lives of students in an ECE context.

By strengthening the above idea, the Ministry of Education has specified five competencies required of school principals [11]. The competences include: lead and facilitate vision of learning, develop and manage school-community relations, lead and manage learning and teaching, lead and develop individuals and team, and lead and manage school operations and resources. Hence, all school principals need to develop essential competencies required for effectively accomplishing their roles. They should serve as educational leaders, responsible for managing the policies, regulations, and procedures to ensure that all students acquired the necessary knowledge, skills and attitudes that meet the approved curricula and mission of the education.

Thus, leadership role is very important because it is responsible for calling for a commitment and passion from every member of the preschool setting to make a contribution which results in a positive difference in the lives of the children in the preschool context and to help lay the foundation which will help them to develop into productive citizens who will be able to live and work productively in increasingly dynamically complex societies.

\section{Statement of the Problem}

The focus of Ethiopia's education policy to date has been on improving primary schools in terms of both access and quality. However, preschool education has been a much lower government priority. The absolute number of trained teachers remains small. The government's stance of providing preschool education, was questioned by academics, NGOs and even by others [9].

Preschool principals as a leader need to be able to manage the parents' different perspective and build up collaborative relationship where parents and schools stand and work together as stakeholders for the benefit of the children they are sharing. Researchers reported that when parents are actively involved in their child's school and classroom the child learns that he or she is very important. However, principals are challenged by a mismatch between parents' expectation and kindergartens' performances.

According to Tirusew early childhood leaders require competent knowledge such as group dynamics, child development and skill like technical and human [16]. They should also demonstrate characteristics such as being goal oriented; have a good relationship with staff and being responsive to teachers and parents. To be such a leader, early childhood principals should be well trained or should get intensive need-based training that focus on the unique needs of early years. However, Getnet, and Ermias reported that kindergartens in Ethiopia exhibit various problems ([6], [4]). Most private preschools use curricula borrowed from other countries. It seems that the government curriculum is simply serving as instruments during accreditation and supervision. Coming to the professional background of preschool principals' one can hardly expect them to have obtained training in preschool education and management since the field itself is non-existent in the country.

MoE conducted a study on the 'Quality and Effectiveness of Teacher Education in Ethiopia', which concluded that the system's ability to provide education in accordance with the goals of the Education and Training Policy was weakened by several factors [9]. The major constraints were identified as large and heterogeneous classes, minimal teaching resources, 
poor physical environment and infrastructure, weak preservice preparation and lack of continuing in-service professional development, an overly academic, often irrelevant and not well-understood curriculum and examination system that discourages active learning, creative thinking and the development of higher-order thinking skills. Poor leadership and weak management skills were also among the identified problems [9].

Wolaita Zone Education Department/ZED/ didn't mentioned about the performance of private pre-schools in its 2016 yearly report. Besides, the researchers informally contacted the educational quality assurance core process owner of Wolaita Zone Edcation Department and discussed about the role of leaders and how they were appointed to the position. However, the researchers understood from the discussion that no attention was given to private preschools because they are considered as business organizations. The researchers got the same response from Sodo City Administration Preschool and Non-formal Adult Education Core Process owner.

Thus, the researchers reviewed the local researches conducted until now and found out that few researches were conducted on early childhood education and problems related to kindergarten curriculum and its implementation. However, issues related to pre-school leadership was not investigated at all. To this end, the researchers interested to conduct a study on leadership influence on the effectiveness of private preschool education in Sodo City Administration. Thus, this study attempted to answer the following basic research questions:

a). To what extent do private preschool leaders play their leadership role in the study area?

b). What are the major challenges of private preschools leaders in Sodo city administration?

\section{Research Design and Methodology}

The research design employed in this study was triangulation research design. The method employed was mixed research method. Wolaita Zone has twelve woredas and three city administrations. The researcher purposively selected Sodo City Administration since there were no private pre-schools in 12 rural woredas; and there were insignificant number of private preschools in Bodit and Areka city administrations.

In Sodo city administration, there are 20 private preschools and all the 20 private preschools were considered in this study. In these schools, there are 120 teachers, and all the teachers were included in the study as respondent. Similarly, all the 20 principals and 6 supervisors leading and supervising the schools were included in the study. In addition, 6 PTSA chairman were included from 20 PTSAs chairman found in the sample schools by using simple random sampling technique. Moreover, two relevant experts from Sodo City Administration Education office were included in the study by using purposive sampling technique and this gives a chance to get more relevant and resourceful individuals.

\section{Discussions and Results}

\subsection{The Roles and Responsibilities of Leaders}

The school, as an organization, is highly reliant on the leadership of the principal. A study conducted in the area depicted that the success and effectiveness of a school relies, among others, on the quality of leadership [20]. The principal works with teachers, students and other stakeholders to bring a definite effect on school improvement, which leads to better student outcomes.

Table 1. Roles and Responsibilities of Leaders.

\begin{tabular}{|c|c|c|c|c|c|}
\hline \multirow[b]{2}{*}{ No } & \multirow[b]{2}{*}{ Items } & \multicolumn{2}{|c|}{ Teachers $(N=120)$} & \multicolumn{2}{|c|}{ Principals $(\mathrm{N}=\mathbf{2 0})$} \\
\hline & & $\begin{array}{l}\text { Mean } \\
\text { Value }\end{array}$ & SD & $\begin{array}{l}\text { Mean } \\
\text { Value }\end{array}$ & SD \\
\hline 1 & Staff development & 3.72 & .912 & 3.71 & .868 \\
\hline 2 & $\begin{array}{l}\text { Monitoring the } \\
\text { learning process }\end{array}$ & 3.98 & .836 & 3.79 & .782 \\
\hline 3 & Conducting research & 2.74 & 1.126 & 2.81 & 1.196 \\
\hline 4 & Decision making & 3.93 & .856 & 3.72 & .946 \\
\hline 5 & Goal clarification & 3.96 & .854 & 3.94 & .741 \\
\hline \multicolumn{2}{|c|}{ Aggregate Mean } & 3.66 & & 3.64 & \\
\hline
\end{tabular}

Table 1 depicts roles and responsibilities of school leaders. As to the responses of teachers and principals, except the role of conducting research work (mean values of 2.74 for teachers and 2.81 for principals) the achievement of the remaining roles was at moderate level. That is, staff development, monitoring learning process, decision-making tasks, and goal clarification were accomplished moderately (mean value between 3-3.99). The implication of this data is that, the role and responsibility of principals with regards to staff development, monitoring the learning process, decision making, and goal clarification had not been accomplished well. That is, failure of leaders to discharge these responsibilities significantly affect the effectiveness of preschools education.

On the same issue the interview participants were requested to explain the most important roles and responsibilities of preschool leaders. The major roles were identified as: set clear and shared vision, coordinate and monitor teaching-learning process, build a strong culture of collaboration, develop community relationship, lead and manage school resources, set appropriate curriculum implementation mechanism, develop team sprit among staffs, encourage self and staffs to professional development. Therefore, the participants clearly understood the important roles and responsibilities of the private preschool leaders however; the principals not accomplished properly the specified roles at school level. 


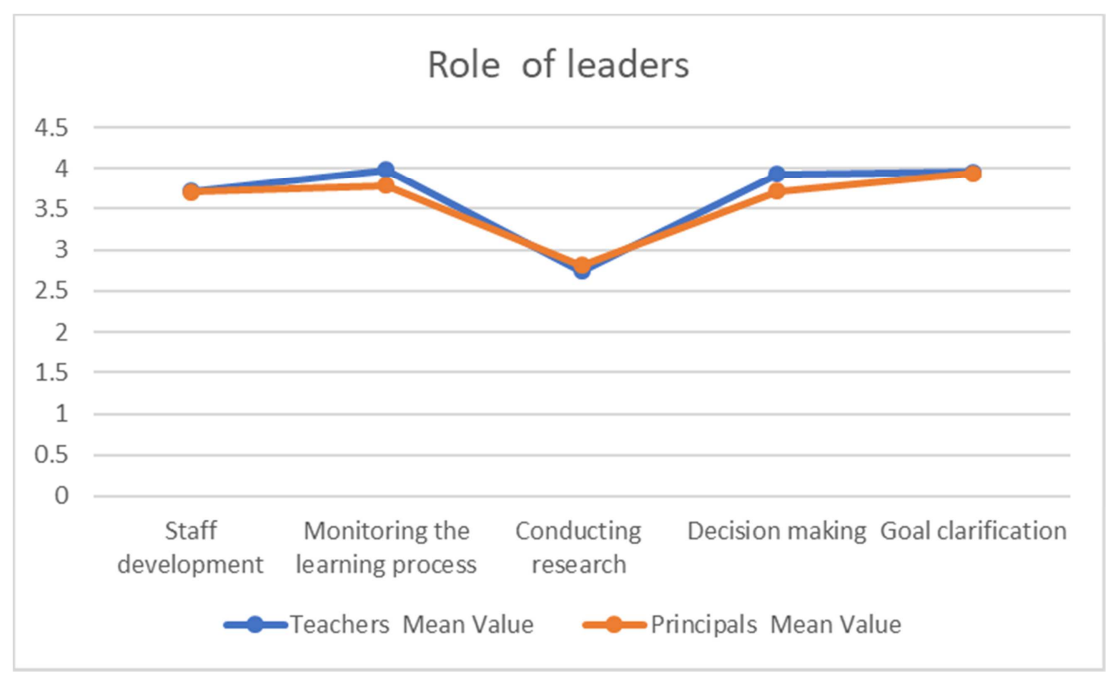

Figure 1. Role of leaders.

\subsection{Challenges of Leaders}

Like any task, leadership is not free from challenges. Hence, knowing the actual and potential challenges and acting accordingly is the quality expected from any leader.

Table 2. Challenges of Leadership.

\begin{tabular}{|c|c|c|c|c|c|}
\hline \multirow{2}{*}{ No } & \multirow{2}{*}{ Items } & \multicolumn{2}{|c|}{ Teachers $(N=120)$} & \multicolumn{2}{|c|}{ Principals $(\mathrm{N}=\mathbf{2 0})$} \\
\hline & & Mean Value & SD & Mean Value & SD \\
\hline 1 & The absence of guidelines & 3.55 & 1.208 & 4.01 & .999 \\
\hline 2 & The absence of clear expectations & 3.82 & 1.053 & 4.15 & .933 \\
\hline 3 & The shortage of school budget & 4.60 & .782 & 4.50 & .946 \\
\hline 4 & Shortage of resources and facilities & 4.61 & .626 & 4.60 & .681 \\
\hline 5 & Teachers turn over & 4.44 & .632 & 4.44 & .821 \\
\hline 7 & Lack professional training for teachers & 4.08 & 1.034 & 4.24 & .813 \\
\hline 8 & Teachers readiness to assume responsibility & 4.18 & .895 & 3.90 & .852 \\
\hline 10 & Existence of various interest groups & 3.98 & .889 & 4.05 & .826 \\
\hline 11 & Mismatch between parents' expectations and school performances & 4.00 & 1.069 & 3.65 & .745 \\
\hline 12 & Interference of external body & 3.84 & .850 & 4.40 & .657 \\
\hline 13 & Lack of communication between staff and management & 3.72 & 1.078 & 3.50 & .946 \\
\hline 14 & Lack of positive relation among management members & 3.67 & 1.103 & 3.75 & .505 \\
\hline 15 & Lack of trust on management & 4.24 & 1.019 & 4.14 & 1.020 \\
\hline 16 & Lack of freedom to exercise academic right & 4.24 & .939 & 3.65 & .813 \\
\hline 17 & Lack of supervision from education office & 4.43 & .753 & 4.21 & .933 \\
\hline 18 & Inconveniency of school location & 4.14 & .745 & 4.14 & 1.210 \\
\hline \multicolumn{2}{|c|}{ Aggregate Mean } & 4.07 & & 4.03 & .772 \\
\hline
\end{tabular}

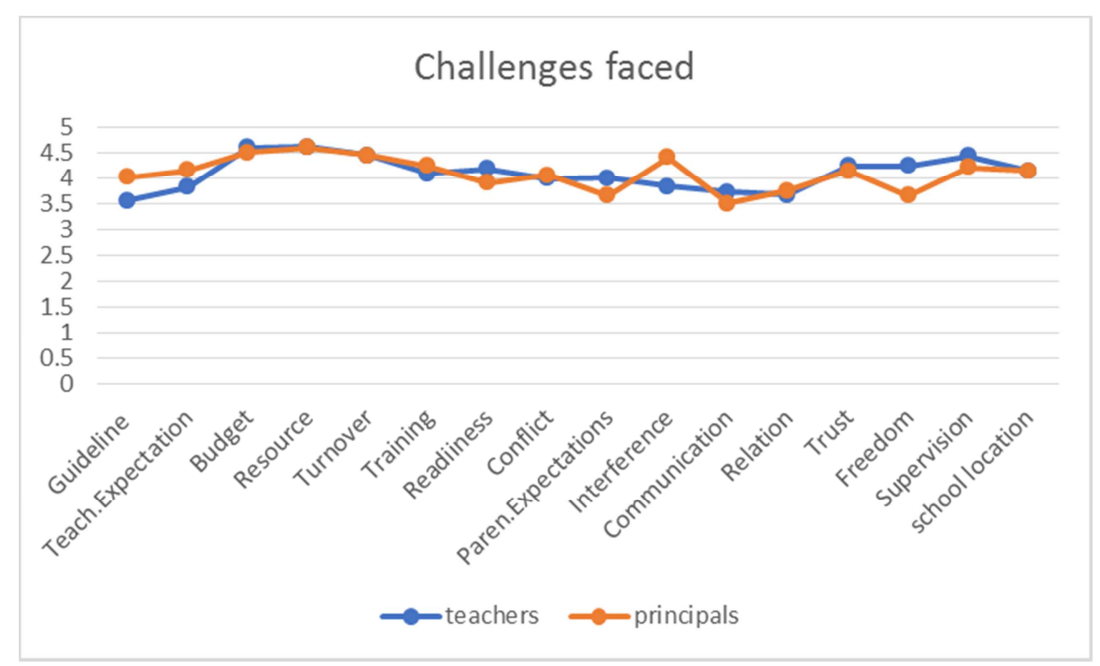

Figure 2. Challenges faced. 
Table 2 presents the respondents' data provided in response to various issues related to the challenges of leadership that hinders accomplishment of different roles and responsibilities in all areas of the preschools and the degree to which the effectiveness of private preschool education was affected.

As indicated in the table above, except the shortage of school budget (mean value 4.50 and 4.60 of principals and teachers respectively), the absence of guide lines, the absence of clear expectation, the absence of on-job, need based, adequate training, the absence of ongoing professional training, teachers turn over, accommodating teachers' interest, behavior and understanding, lack of encouragement and trust from senior management, interference of senior management, poor supervision and inconvenient of school location were to be rated by principals' respondents high with its mean value 4 . However, teachers' respondents were rated the item of the absence of guidelines, the absence of clear expectation, and teachers' readiness to assume responsibility were to be rated moderate as the mean value is in between 3-3.99.

On the other hand, the teachers' respondents have similar perception with principals' on the shortage of school budget (which was rated to be very high), the absence of need based on-job, adequate training, the absence of ongoing professional training, accommodating teachers' interest, behaviour and understanding, lack of encouragement and trust from senior management, poor supervision and inconvenient of school location were to be rated high with mean value 4 .

Except the shortage of school budget, therefore, those the above mentioned items (the absence of on-job, need based, teachers turn over, adequate training, the absence of ongoing professional training, accommodating teachers' interest, behaviour and understanding, lack of encouragement and trust from senior management, interference of senior management, poor supervision and inconvenient of school location) highly challenged leaders role and in turn affected the effectiveness of private preschools. Besides, the shortage of school budget was serious problem for principals as it was rated by both teachers' and principals' respondents' high with mean value 4.50 and 4.60 respectively.

Moreover, the absence of guide lines, the absence of clear expectation, the absence of on-job, need based, adequate training, the absence of ongoing professional training, accommodating teachers' interest, behaviour and understanding, lack of encouragement and trust from senior management, interference of senior management, poor supervision and inconvenient of school location were highly challenged leaders role and in turn affected the effectiveness of private preschools as perceived by principals.

Regarding to items such as staff being diverse in educational background and expectations, lack of open communication between staff and management, absence of active and positive interaction between managements were rated by both principals and teachers' respondents moderate with mean value in between 3-3.99. Whereas mismatch between parents' expectations and school performances and freedom to exercise full power were rated by teachers respondents high with mean 4 .

Above all, the aggregated mean value of teachers (4.07) and principals (4.03) indicates all the mentioned items were high challenges of leaders to carry out roles and responsibilities effectively in private preschools. This is because, managing and leading in kindergarten setting is characterized by the experience and environment provided for the children; the relationship between teaching staff and non-teaching staff, teachers and administration and between adults and children [19].

Moreover, Pugh [13] reported that leadership is very important and challenging as principals have many responsibilities to many different people (teachers, teaching assistants, babysitters, children supervisors and cleaners). Regarding to high challenges of poor supervision the respondents complaining, the government is promised to involve in developing curriculum, training teachers, and providing supervisory support MoE [10]. The number of kindergartens is increasing every year, particularly in urban areas.

Moreover, the researcher conducted interview with private preschool leaders and major challenges identified were, lack of safe and conducive physical and learning environment, lack of resources: materials (teaching learning facilities), human resources (professional background of principals and teachers), high teachers' turn over, huge variability of curriculum across the schools, lack of separate place for preschool students, a mismatch between parents' expectation and kindergartens' performances, interference of senior management/owner/, poor supervision and support from education office

Furthermore, the informants shared their view whether private preschool principals qualified, competent, and unique character in early childhood education, and how it was defined. As they stated during the interview session, early childhood education is the stage at which preparatory education for the regular education is provided. They also added it was not actual learning stage, according to the informants, that is why it is called "pre-school". Most preschool leaders were not qualified and competent for the position. They did not possess the necessary training in leadership and childhood development. According to Bloom (2000), early childhood leaders require competent knowledge such as group dynamics, child development and skills like technical and human. They should also demonstrate characteristics such as being goal oriented; have a good relationship with staff and being responsive to teachers and parents. To be such a leader, early childhood principals should be well trained or should get intensive need-based training that focus on the unique needs of early years.

\section{Conclusions}

From the findings of the study, the following conclusions 
were drawn:

The role and responsibilities of leaders were implemented moderately in articulating collective vision, goal clarification, monitoring the teaching learning process, staff development, developing research work, making decision, knowledge in early child development, encouraging open communication, and creative problem solving. Thus, the roles and responsibilities played by the private preschool principals were moderate to achieve the objectives of the school which in turn affected the effectiveness of private preschool education.

The study findings also show that there were many challenges encountered by preschool leaders which affected the effectiveness of preschool education. These includes: the absence of guidelines and clear expectations, shortage of resource and facilities, high turnover of teachers, lack of incentive and low salary, absence of on-job trainings, irregularity or lack of uniformity of curriculum, lack of qualified teachers in the $\mathrm{KG}$, lack of safe and conducive teaching learning environment, lack of school facilities, separate compound for pre-schools, etc. Kindergarten principals' leadership knowledge, qualification, and training in the field of early childhood education and care are very critical for the effectiveness of the schools. Therefore, the preschool leaders were challenged by a number of factors that influence in accomplishing their roles as expected that resulted in ineffectiveness of private preschools.

Therefore, it is possible to conclude that the roles and responsibilities played by the private preschool principals were moderate to achieve the objectives of the school, which in turn affected the effectiveness of private preschool education. In addition, private preschool leaders challenged by several factors, which hindered them from playing their leadership roles, and responsibilities.

\section{References}

[1] Blatchford and Laura (2006). The Effective Provision of Preschool Education (EPPE) project: Intensive case studies of practice across the Foundation Stage. London: Institute of Education, University of London.

[2] Carneiro P., Crawford and Goodman, (2006). Which Skills Matter? Center for the Economics of Childhood in Focus 4, the Open University.

[3] Currie, J. (2001). Early Childhood Education Programs, Journal of Economic Perspective Volume 15, Number 2

[4] Ermias Sebsbe (2013). The Status of Early Childhood Education In Selected Private Kindergarten In Nifasilk Lafto Subcity, Addis Ababa AAU, unpublished

[5] Fligstein, N., and Freeland, R. (1995). Theoretical and
Comparative Perspectives on Corporate Organizations. Annual Review of Sociology, 21, 21-43.

[6] Getenet Hailemicael (2013). An Assessment of Kindergarten Curriculum Implementation in Selected Kindergarten, Addis Ababa, Ethiopia. AAU unpublished.

[7] Heckman (2006). 'Skill Formation and the Economics of Investing in Disadvantaged Children'. Leadership. 60 (7), 5863.

[8] Kivunja, C., and Power, A. (2006). 'A New Dynamics Paradigm for Analyzing Structural and Cultural Dynamics in an Educational Organization'. Proceedings of the AARE 2006 International Education Research Conference: Engaging Pedagogies, Adelaide, 26-30 November 2006.

[9] MoE (2002). Education Sector Development Program II 2002-5. Addis Ababa.

[10] MoE (2010). Education Sector Development Program I 2010/20112014/2015. Addis Ababa.

[11] MoE (2013). Frame Work for Pre-primary Education Inspection; Addis Ababa.

[12] Mulford. W., Silins, H., and Leithwood, K. (2004). Educational Leadership for Organizational Learning and Improved Student Outcomes. London: Kluwer Academic Press. NZ

[13] Pugh, G. (2001). Contemporary Issues in the Early Years: Working Collaboratively for Children: 2nd ed. London: Paul Chapman Publishing Ltd/ National Children Bureau.

[14] Silins, H., and Mulford, B. (2002). Schools as Learning Organizations: The Case for System, Teacher and Student Learning. Educational Administration, 40, 425-446.

[15] Sylva, K., Melhuish, E. C., Sammons, P., Siraj-Blatchford, I. And Taggart, B. (2004); The Effective Provision of Preschool Education (EPPE) Project: Final report. London: DIES/Institute of Education, University of London.

[16] Tirussew Tefera (2007). Status of Early Child hood Care and Education, Ministry of Education in collaboration with UNICEF

[17] Truskie, S. D. (2002). Leadership in High Performance Organizational Cultures. London: Quorum Books.

[18] Vygotsky, L. S. (1929). The Problem of the Cultural Development of the Child. Journal of Genetic Psychology, 36, 415-434.

[19] Waniganayake, M. (2000). 'Leadership in Child center: is it Just another job? Australian Journal of Early Childhood,. 28 (1)

[20] West-Burnham, J. (2001). 'Interpersonal leadership, NCSL Leading Edge Seminar', Nottingham: National College for School Leadership.

[21] Yukl G. (2010). Leadership in organizations (7 ${ }^{\text {th }}$ ed.). New Jersey: Pearson Education, Inc. 